Античная древность и средние века. Т. 48. С. 349-367

УДК 72.04(477.75)“13”

DOI 10.15826/adsv.2020.48.022

\author{
В. П. Кирилко \\ Институт археологии Крыма РАН \\ Симферополь, Россия

\section{НЕКОТОРЫЕ АРХИТЕКТУРНЫЕ ДЕТАЛИ КРЫМСКОГО МЕДРЕСЕ ИНДЖИ-БЕЙ ХАТУН}

На основании материалов археологического изучения памятника и иконографических источников предметно рассматриваются отдельные архитектурные детали медресе в г. Крым (Солхат, совр. Старый Крым, бывш. Эски-Кырым), построенного в 733 г. х. (= 1332/1333 г.) по указанию Инджи-бей Хатун, дочери бея Кыл-Буруна. Результаты исследования позволяют достоверно восстановить первоначальный облик входов в жилые помещения здания. Дверные проемы худжр были однотипными, местами наблюдается незначительная разница в размерах. Несмотря на четко выделенный центр и доминанту в виде монументального портала, обозначившего продольную ось строения, главный фасад медресе имел асимметричную композицию. Его стороны отличались между собой разным количеством и расположением не только окон, но и каменных водосточных желобов. Конструкция и форма проемов, использовавшихся для освещения восточных худжр, поддается достоверной реконструкции. Основные плоскости главного фасада были украшены профилированными выступами, которые полностью обрамляли стену по периметру, одновременно выделяя цоколь и оконтуривая наличники окон. Самым проблематичным является детальное воссоздание утраченных форм портала, представленного в общих чертах на акварели М. М. Иванова. В настоящий момент не вызывает сомнений использование для внешнего обрамления портала сплошной профилированной тяги, которая позволяла выделить, четко ограничив с тыльной стороны и сверху, его основные поверхности. Графическое восстановление всего сооружения в мельчайших подробностях в значительной мере зависит от введения в научный оборот абсолютно всех архитектурных, конструктивных и декоративных деталей, найденных на территории Старого Крыма и особенно тех, что были получены при раскопках самого здания.

Ключевые слова: средневековый Крым; архитектура Золотой Орды; сельджукский стиль; медресе; Инджи-бей Хатун; портал; графическая реконструкция здания

Благодарности: Исследование подготовлено в рамках выполнения плановой темы отдела средневековой археологии Института археологии Крыма РАН «Взаимодействие культур и цивилизаций в средневековом Крыму».

Цитирование: Кирилко В. П. Некоторые архитектурные детали крымского медресе Инджи-бей Хатун. DOI 10.15826/adsv.2020.48.022 // Античная древность и средние века. 2020. Т. 48. С. 349-367.

Поступила в редакичию: 26.05.2020

Принята к печати: 15.10 .2020

() Кирилко В. П., 2020 


\author{
В. П. Кирилко
}

\author{
Vladimir P. Kirilko \\ Institute of Archaeology of the Crimea of the Russian Academy of Sciences \\ Simferopol, Russia
}

\title{
ARCHITECTONIC MEMBERS FROM INDZHI-BAY HATUN MEDRESE IN THE CRIMEA
}

This article uses the materials of archaeological researches of the monuments and iconographic sources to make a detailed analysis of some architectonic members the medrese in the town of Krym (Solkhat; now Staryi Krym, formerly Eski-Kyrym), which was built in $733 \mathrm{AH}(=1332 / 33 \mathrm{AD})$ by the order from Indzhi-Bay Hatun, a daughter of Kyl-Burun Bay. The results of the research allow a reliable restoration of the original appearance of the entrances to the living rooms of the building. The doorways of the hujras belonged to the same type, with inconsiderable difference of dimensions at some places. Despite the clearly distinguished centre with the dominant monumental portal designating the longitudinal axis of the structure, the medrese's main facade had an asymmetric composition. Its sides had different numbers and arrangement of windows and stone gutters. The design and shape of the openings which illuminated eastern hujras are reconstructed with reliability. The basic planes of the main facade were decorated with profiled protrusions that completely framed the wall around the perimeter, simultaneously highlighted the basement and contoured the window frames. The most problematic is a detailed reconstruction of the lost forms of the portal which general outline appears on M. M. Ivanov's watercolours. So far there is no doubt concerning the solid profiled reglet which framed the portal on the outer side: it outlined the portal's main surfaces by limiting them above and on the back side. The graphic reconstruction of the whole structure with its minor details depends, to a great extent, on the introduction into the scholarship of absolutely all architectural, structural and decorative members discovered in Staryi Krym and especially those excavated from the building in question.

Keywords: mediaeval Crimea; Golden Horde architecture; Seljuk style; medrese; Indzhi-Bay Hatun; portal; graphic reconstruction of a building

Acknowledgement: This research has been prepared within the project on the "Interaction of Cultures and Civilizations in the Medieval Crimea" at the Medieval Archaeology Department of the Institute of Archaeology of the Crimea of the Russian Academy of Sciences.

For citation: Kirilko, V. P. (2020). Nekotorye arkhitekturnye detali krymskogo medrese Indzhi-bei Khatun [Architectonic Members from Indzhi-Bay Hatun Medrese in the Crimea]. Antichnaya drevnost' $i$ srednie veka, 48, 349-367. doi: 10.15826/ adsv.2020.48.022 
Некоторые архитектурные детали крымского медресе

Воистину непреходящим оказалось предупреждение одной из публикаций почти вековой давности, к сожалению, сохранившее свою актуальность до сих пор: «Исчерпывающих данных об этом памятнике мы в настоящей статье не дадим, так как памятник, начатый обследованием летом 1925 г., еще не дообследован» ${ }^{1}$. Изучение средневекового медресе в г. Старый Крым (бывш. Эски-Кырым, Крым, Солхат), предпринятое тогда археологической экспедицией Крымсовнаркома, Крымцика и Научной ассоциации востоковедения СССР под руководством И. Н. Бороздина, внезапно прекратилось в 1928 г. и было продолжено лишь спустя пятьдесят лет, в 1978 г. М. Г. Крамаровским. Последнее стало возможным во многом благодаря усердию О. И. Домбровского, которому удалось обратить внимание региональных чиновников на удручающее состояние и значимость древнего строения, что, в свою очередь, после длительного забвения позволило возобновить раскопки руин средневекового мусульманского университета, доверив их проведение самому лучшему профильному специалисту Государственного Эрмитажа, а также приступить к ремонтно-реставрационным работам, используя местные кадры ${ }^{2}$. Изыскания все еще продолжаются ${ }^{3}$.

История исследования этого медресе, построенного по указанию Инджи-бей Хатун в 733 г. х. (=1332/1333 г.), и основные сведения об архитектонике здания, полученные при разработке проекта консервации, мной относительно подробно и практически полностью (по состоянию на 2009 г.) уже опубликованы ${ }^{4}$. Созданный таким образом задел

${ }^{1}$ Башкиров А. С. Сельджукизм в древнем татарском искусстве // Крым. 1926. № 2. С. 109.

${ }^{2}$ Кирилко В. П. Солхатское медресе // Stratum plus. 2011. № 6. С. 126-156; Он же. Реставрация архитектурного комплекса XIV-XVI вв. «Медресе-мечеть Узбека в г. Старый Крым»: успехи, неудачи и перспективы // Актуальные проблемы изучения и сохранения исламского наследия Крыма / ред. А. Исмаилов, Э. Муратова, С. Эминова. Симферополь, 2014. С. 82-88.

${ }^{3}$ Крамаровский М. Г., Сейдалиев Э. И. Археологические исследования Старокрымской археологической экспедиции Государственного Эрмитажа в 2001-2018 гг.: итоги и перспективы // XX Боспорские чтения. Боспор Киммерийский и варварский мир в период античности и средневековья. Основные итоги и перспективы исследований / ред. В. Н. Зинько, Е. А. Зинько. Симферополь ; Керчь, 2019. С. 325.

${ }^{4}$ Кирилко В. П. Солхатское медресе... С. 125-210. Существенным упущением данного исследования является отсутствие сведений о раскопках 1928 г. По совершенно непонятным сейчас причинам вне внимания автора оказалась обзорная статья, упоминающая эти работы (Эрнст Н. Л. Летопись археологических раскопок и разведок в Крыму за 10 лет (1921-1930 г.) // ИТОИАЭ. 1930. T. IV. С. 87), и, как следствие, используемые им в качестве иллюстраций фотографии того времени ошибочно датированы 1926 г. В свою очередь, хронологический сбой повлек за собой неправильную идентификацию отдельных участников экспедиции, групповой портрет которых на фоне входа в худжру запечатлен одним из снимков (Кирилко В. П. Солхатское медресе... Рис. 37). В настоящий момент допущенные неточности исправлены в новой публикации архивного источника (Мирас - Наследие. Татарстан - Крым. Город Болгар и изучение татарской культуры в Татарстане и Крыму в 1923-1929 годах : в 3 т. / ред. С. Г. Бочаров, А. Г. Ситдиков. Т. 2. Казань, 2016. Рис. 237). 


\section{В. П. Кирилко}

способствует дальнейшему изучению памятника ${ }^{5}$, поскольку позволяет, не отвлекаясь на неизбежные пространные описания, предметно рассмотреть отдельные уцелевшие детали строения, которые в свое время были представлены лишь в общих чертах либо не упоминались совсем, хотя и заслуживают более пристального внимания.

К числу таких сооружений в первую очередь, безусловно, следует отнести дверные проемы худжр, сохранившиеся сравнительно хорошо и поддающиеся предельно достоверной реконструкции. Медресе имело четырнадцать специальных помещений, которые предназначались для проживания в них учащихся. Они располагались компактно рядами вдоль внешних стен здания по периметру с трех сторон, занимая пространство между боковыми айванами и аудиториями, а также южным айваном и входной экседрой (ил. 1). В разной степени уцелевшие входы двенадцати комнат относительно полностью изучены ${ }^{6}$. В большинстве своем их остатки представлены сильно поврежденными кладками нижней части конструкции, однако в нескольких случаях раскопками удалось обнаружить in situ даже верхние фрагменты наличников и следы перекрытий проема, что в совокупности дает надежное основание для восстановления первоначального облика сооружения и его декоративного убранства (ил. 2). Все входы в худжры были однотипными, местами наблюдается незначительная разница в размерах.

Дверной проем в плане прямоугольный с четвертями. Снаружи он обрамлен рельефным наличником и завершался архитравом с дуговидным вырезом, выполненных из чисто тесаных блоков и плит известняка разной величины. Перекрытие его остальной части представляло собой сплошной накат из трех дубовых брусьев. Дверь была двухстворчатой, открывалась вовнутрь. Гнезда подпятников овальной формы с немного скругленным дном. Основные размеры входа: просвет - 0,62 м, ширина со стороны помещения - 0,82 м, внешняя и внутренняя высота - 1,52 и 1,7 м, глубина проема - 0,55 м. Ширина и толщина четверти - около $0,18^{7}$ и 0,09 м. Высота порога - 0,05 м. Над уровнем двора вход возвышался на $0,2-0,4$ м, что местами обусловило появление приступка.

\footnotetext{
${ }^{5}$ Крамаровский М. Комплекс мечети и медресе Солхата: актуальные проблемы изучения и сохранения // Актуальные проблемы изучения и сохранения исламского наследия Крыма / ред. А. Исмаилов, Э. Муратова, С. Эминова, Н. Абдульвапов. Симферополь, 2014. C. 205.

${ }^{6}$ Кирилко В. П. Солхатское медресе... С. 186-188, рис. 17-19, 51, 33, 37, 89-99, 110; Мирас - Наследие... Т. 2. Рис. 139, 188, 261, 344; Мирас-Наследие... Т. 3. Рис. 769, 783, $787,788,791$.

${ }^{7}$ Отмечены также иные варианты. Например, в угловой юго-восточной худжре (пом. 5) толщина четверти равна 21,5 cм, а в соседнем с ней помещении она составляет $20 \mathrm{~cm}$.
} 
Некоторые архитектурные детали крымского медресе

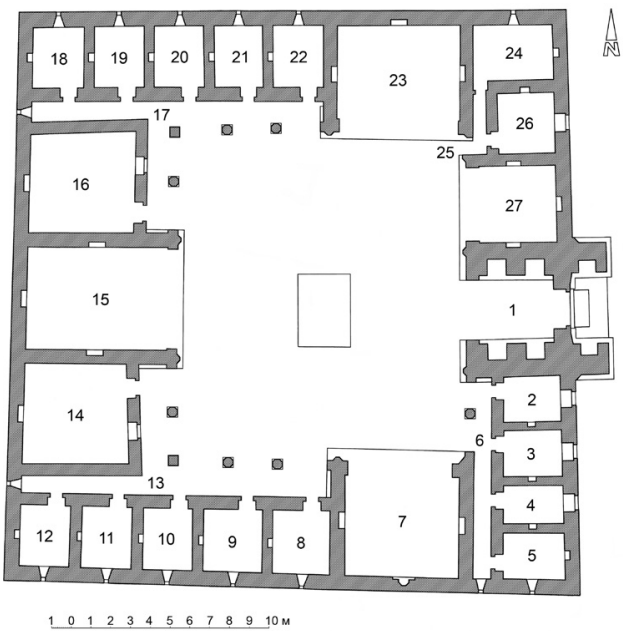

Ил. 1. План медресе. Реконструкция. Чертеж автора

Fig. 1. Ground plan of the medrese. Reconstruction. Drawn by the author
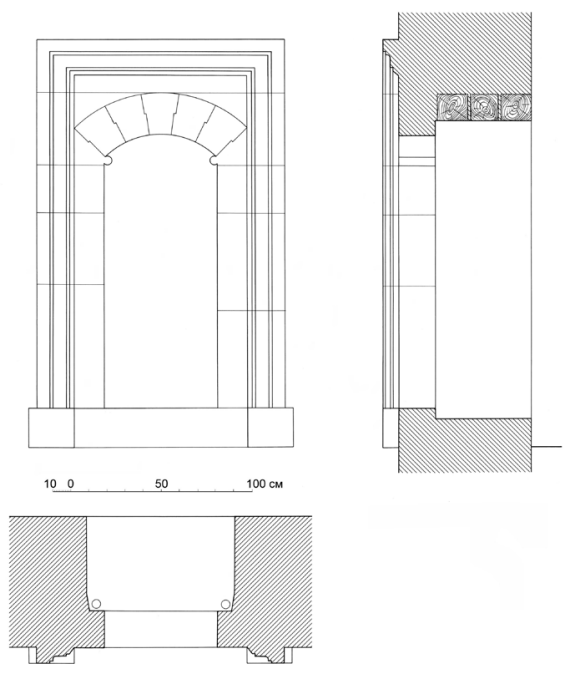

Ил. 2. Вход в худжру. Вид, план и разрез. Реконструкция. Чертеж автора

Fig. 2. The entrance to the hujra. A view, ground plan, and cross-section. Drawn by the author 


\section{В. П. Кирилко}

К числу характерных особенностей архитектоники дверного проема худжр следует отнести несколько выразительных его деталей, получивших свое применение также при оформлении других подобных, но отличавшихся бо́льшим просветом, входов медресе, которые вели в аудитории и дюрбе (пом. 14-16) 8 . В частности, порог фланкирован двумя блоками известняка в виде консолей, вынесенных за плоскость стены. Они служили опорами для рельефного обрамления двери, украшавшего проем с боков и сверху. В общих массах сечение выступающей части наличника четко вписывается в прямоугольную трапецию. Ее передняя и внешняя боковая стороны в плане обычно совпадают с контурами подножия, а тыльная находится на одной линии с фасадной плоскостью четверти. Лицевая поверхность углового участка призмы по внутреннему обводу профилирована тремя полочками, расположенными каскадом - двумя узкими по краям и одной широкой с выкружкой между ними. Размеры наличника $2,02 \times 1,36$ м. Сечение рамки: ширина $-18,7$ см, толщина $-8,5-9$ cм.

Снаружи архитрав декорирован контурным изображением сегментивной арки с уступчатыми швами на боковых стыках всех пяти ее клиньев. Имитация выполнена врезной линией с треугольным профилем желобка. Дуга составляет четверть окружности. Радиус фигуры: внутренний $-0,44$ м, внешний - 0,68 м. Судя по характерным сколам лицевой поверхности одного из частично уцелевших in situ архитравов, место сопряжения боковой плоскости четверти с ложной аркой перемычки было украшено трехчетвертным валом, возможно, в виде жгута 9 . Размещение подобных элементов на уровне обоих пят свода дверного проема является достаточно распространенной практикой в средневековом зодчестве Малой Азии. Они имели самые разнообразные, порой достаточно причудливые формы, а их использование обычно обуславливалось технологическими причинами - необходимостью обеспечить временную опору для поддерживающей конструкции арки при возведении последней. В случае с входами худжр солхатского медресе эта консоль, будучи рудиментом, представляет собой исключительно декоративную деталь. Ближайшими аналогиями ей являются идентичные, причем сохранившие свое основное назначение, цилиндрические выступы в порталах двух крымских построек - местной мечети Узбека, датированной 714 г. х. (= 1314 г. $)^{10}$ и мечети с. Колечь, обрамление дверного проема которой представляет собой сполию XIV в. неизвестного происхождения ${ }^{11}$.

\footnotetext{
${ }^{8}$ Кирилко В. П. Солхатское медресе... С. 183-185, рис. 22-23, 27, 82-86; Мирас - Наследие... Т. 2. Рис. 169, 208, 209, 220, 232, 256, 258, 309, 329.

${ }^{9}$ Кирилко В. П. Солхатское медресе... С. 188, рис. 90-91.

${ }^{10}$ Он же. Портал крымской мечети Узбека // Stratum plus. 2015. № 6. Рис. 13-14.

${ }^{11}$ Он же. Сполии в архитектуре Крымского ханства // Материалы Конгресса исламской археологии России и стран СНГ / ред. Х. М. Абдуллин, А. Г. Ситдиков. Казань, 2016. С. 164; Мирас - Наследие... Т. 2. Рис. 513, 515.
} 
Некоторые архитектурные детали крымского медресе

Первоначальный вид медресе Инджи-бей Хатун получил свое отражение в нескольких иконографических источниках. В конце XVIII в. (в 1783 и 1797 гг.), незадолго до окончательного превращения здания в руину, его успел запечатлеть М. М. Иванов, довольно точно представив в трех акварельных рисунках изображения портальной части (ил. 3 ) и внутреннего дворика университета ${ }^{12}$. Имеется также еще одна, более живописная, версия последнего, которая выполнена Жаном-Бальтазаром де ля Траверса в 1798 г. ${ }^{13}$ Судя по относительно поздней дате самой работы и характерным деталям антуража, ее сюжет и композиция, вероятнее всего, им позаимствованы у предшественника. На нескольких карандашных эскизах В. О. Руссена, появившихся в 1843 г. - спустя чуть более полувека после создания ранних произведений М. М. Иванова, портала и передней стены строения уже нет. На их месте виднеются лишь каменные развалы, но зато внимание автора привлекли частично сохранившиеся арочные завершения входов в худжры ${ }^{14}$.

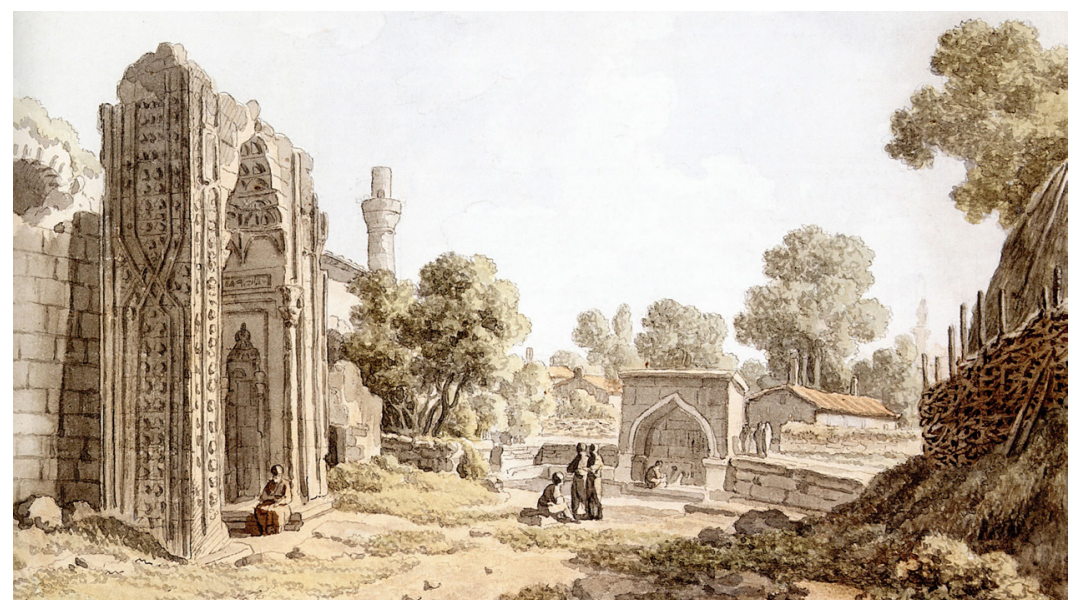

Ил. 3. Портал медресе. Вид с юго-востока. Акварель М. М. Иванова. 1783 (по: Виды Крыма... Рис. 22)

Fig. 3. The portal of the medrese. Viewed from the south-east. Watercolour by M. M. Ivanov. 1783 (according to: Vidy Kryma... Fig. 22)

${ }^{12}$ Кирилко В. П. Солхатское медресе... С. 127, 208, рис. 3-5; Виды Крыма из путевого альбома М. М. Иванова (к 270-летию со дня рождения художника) / ред. М. Р. Мальгина. Симферополь, 2017. С. 10, 62-65, рис. 22, 23.

13 Александрова Н. Жан Балтазар де ла Траверс. «Путешествующий по России живописец». М., 2000. С. 103, 115, № 56, 95.

${ }^{14}$ Петрова Э. Б. Исторический и художественный альбом Тавриды Евгения де Вильнева и Викентия Руссена. Феодосия ; Симферополь, 2015. С. 39-40, рис. 3-5. 


\section{В. П. Кирилко}

Несмотря на существенную информативность изображений, ни один из упомянутых рисунков полного представления о фасадах и высоте постройки не дает. Тем не менее, исключительно четкая архитектоника самого медресе позволяет достаточно уверенно, по крайней мере в общих чертах, реконструировать утраченные части объемно-плановой структуры здания и определить его отдельные размеры. Характерной особенностью строения является то, что все айваны и основные помещения, исключая коридоры, галереи и приспособленную позднее под дюрбе аудиторию, завершались каменными сводами стрельчатой формы, основания которых независимо от ширины компартиментов, имевшей разное значение, везде находились практически на одной отметке ${ }^{15}$. При этом их стены в обязательном порядке по внутреннему периметру завершались карнизом из одного ряда плинфы, на уровне пят поддерживавшим перекрытия ${ }^{16}$. Поскольку стрела подъема конструкции напрямую зависела от величины пролета, которая даже в расположенных смежно однотипных жилых комнатах была различной, шелыги всех худжр, аудиторий и айванов находились на разной высоте.

Минимизировать эстетические потери от неизбежной хаотичности общего силуэта сводов и придать строению целостность позволили наружные стены, в качестве своеобразного экрана ограждавшие внутреннее пространство всех компартиментов и крышу с внешней стороны, с улицы и со двора. Фасады медресе в своей верхней части были уступчатыми, подтверждением чему являются уцелевшие практически в первоначальном состоянии остатки северного айвана. Редкую сохранность кладкам последнего обеспечил возведенный позднее над ними южный щипец мечети. Граница, разделявшая раннее сооружение и ремонтные дополнения, а также места, где начинались прямоугольные уступы, фиксируются довольно четко ${ }^{17}$. Разница в отметках между завершением айвана и находившимися ниже фасадными кладками худжр была не менее 1,5 м. Общая высота здания с северной стороны составляла около 9 м. Передняя стена строения возвышалась над уровнем земли на 7,5 м, что позволяло полностью скрыть за ограждением своды

\footnotetext{
${ }^{15}$ Кирилко В. П. Солхатское медресе... С. 203-208, рис. 52-55, 128.

16 Такая архитектурно-конструктивная деталь отсутствует только в одном месте медресе - на задней стене северного айвана, которая была общей (т. е. одновременно принадлежала соседнему строению) с так называемой мечетью Узбека, что, в свою очередь, является еще одним свидетельством полного обновления здесь кладок на рубеже XVXVI вв. (Он же. Строительная периодизация т. н. мечети Узбека в Старом Крыму // Генуэзская Газария и Золотая Орда / ред. С. Г. Бочаров, А. Г. Ситдиков. Кишинев, 2015. С. 524, рис. 14), в частности, приведшего к утрате карниза.

${ }^{17}$ Он же. Солхатское медресе... Рис. 128-129; Он же. Строительная периодизация... Рис. 18.
} 
Некоторые архитектурные детали крымского медресе

восточных компартиментов, ощутимо отличавшихся друг от друга пролетом и стрелой подъема.

Наиболее сложным для реконструкции является главный фасад медресе, претерпевший существенные утраты. Возвращаясь к иконографическим источникам, видим, что М. М. Иванов на своем рисунке основное внимание уделил преимущественно полуразрушенному порталу постройки, руины которого сейчас сохранились и того меньше, на высоту всего 0,5-1,7 м. Переднюю стену здания он изображает немного утрированно, как монументальную квадровую кладку с абсолютно ровной лицевой поверхностью, что верно лишь в определенной мере ${ }^{18}$. Самая нижняя (наземная) часть конструкции, в то время скрытая от взгляда художника отложениями культурного слоя, представляет собой цоколь (ил. 4). Высота

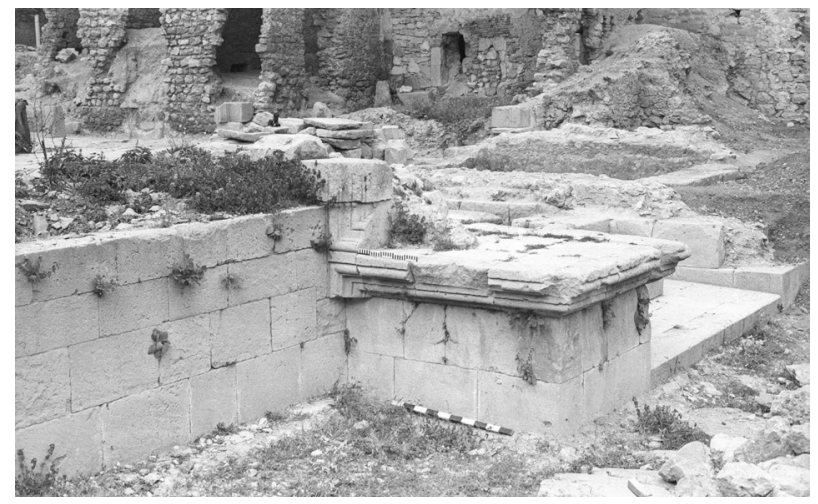

Ил. 4. Портал медресе. Современное состояние. Вид с юго-востока. 1983 (по: Кирилко В. П. Солхатское медресе... Рис. 62)

Fig. 4. The portal of the medrese. Current state. Viewed from the south-east. 1983 (according to: Kirilko, V. P. Solkhatskoe medrese... Fig. 62)

\footnotetext{
${ }^{18}$ В частности, окно худжры у портала (пом. 2), наличие которого подтверждается материалами архитектурно-археологических исследований (Кирилко В. П. Солхатское медресе... С. 161-162, рис. 13) на акварели М. М. Иванова не показано, что, вероятнее всего, было обусловлено почти полной его утратой в тот момент и попыткой художника придать благообразие сильно поврежденным местам (зияющему вывалу?) строения на первом плане. Возможно, поэтому позднее в студийной работе, созданной им по мотивам натурного рисунка, недостоверное место первоначального эскиза он практически полностью спрятал за изображением лачуги, переместив ту из другой старокрымской зарисовки и тем самым, надо полагать, устранил неизбежные для профессионала угрызения совести, вызванные преднамеренно допущенным искажением вида постройки. Последнее косвенно подтверждается также тем, что подобным образом художник тогда же изменил форму «сельджукской цепи» на пилоне портала, причем в обоих случаях плетенка изображена неправильно (Там же. С. 127, прим. 5, рис. 5; Виды Крыма... С. $10,60-61$, рис. 21,22$)$.
} 


\section{В. П. Кирилко}

данного сооружения у портала равна 1,43 м. Его толщина составляет 0,82 м. Фасадная сторона кладки выполнена на известковом растворе из тщательно отесанных и хорошо пригнанных блоков известняка, тыльная часть и заполнение внутреннего пространства конструкции бутовые ${ }^{19}$.

В качестве своеобразного кордона цоколь по всей длине завершался профилированным каменным выступом, остатки которого были обнаружены in situ при архитектурно-археологическом изучении памятника $^{20}$. Средняя часть этой детали сохранилась на протяжении 1,9 м, представлена тремя компактно расположенными блоками известняка с сильно деструктированной лицевой поверхностью (ил. 5-7). Еще один крупный фрагмент сооружения, в свое время находившийся непосредственно у портала, сейчас безвозвратно утрачен и известен исключительно по архивным фотографиям (ил. 8). Несмотря на существенные повреждения, их форма и размеры поддаются достоверному определению. Высота детали - 30,1-30,6 см. За плоскость цоколя она выступала на 4,3 см. Ширина рельефа - 15,3-16,2 см. На расстоянии $1,6-1,8$ см от внешнего края, между двумя поясками разной величины, находится полувал с диаметром $3,8(4,2)$ см. С внутренней стороны эта часть изделия посредством небольшой полочки, которая на отдельных местах фасада (на наличниках окон) отсутствует, и фаски соединялась с плоскостью стены, везде равномерно западавшей по отношению к поверхности цоколя примерно на 1,5 см.

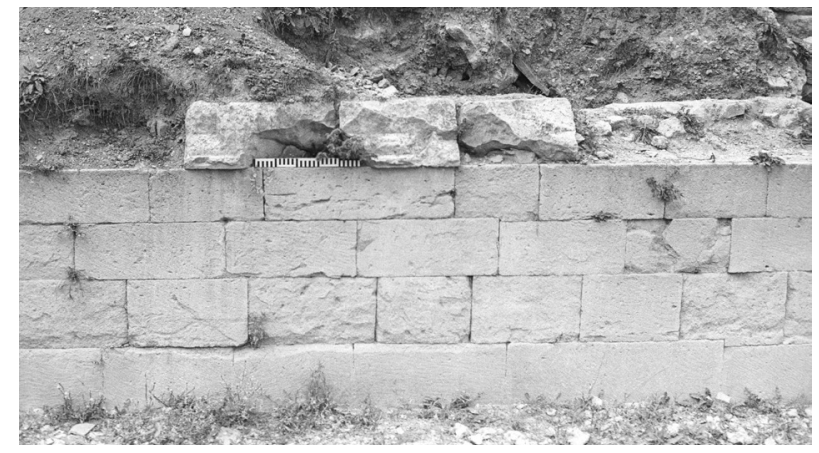

Ил. 5. Обрамление передней стены медресе. Фрагмент. Вид с востока. 1983 (по: Кирилко В. П. Солхатское медресе... Рис. 57)

Fig. 5. The border of the front wall of the medrese. Fragment. Viewed from the east. 1983 (according to: Kirilko, V. P. Solhatskoe medrese... Fig. 57)

\footnotetext{
${ }^{19}$ Кирилко В. П. Солхатское медресе... С. 158, рис. 52, 56-57, 62-63.

${ }^{20}$ Там же. Рис. 13; 17; 52: 1; 57-58; Мирас- Наследие... Т. 2. Рис. 122, 185, 213, 254.
} 
Некоторые архитектурные детали крымского медресе
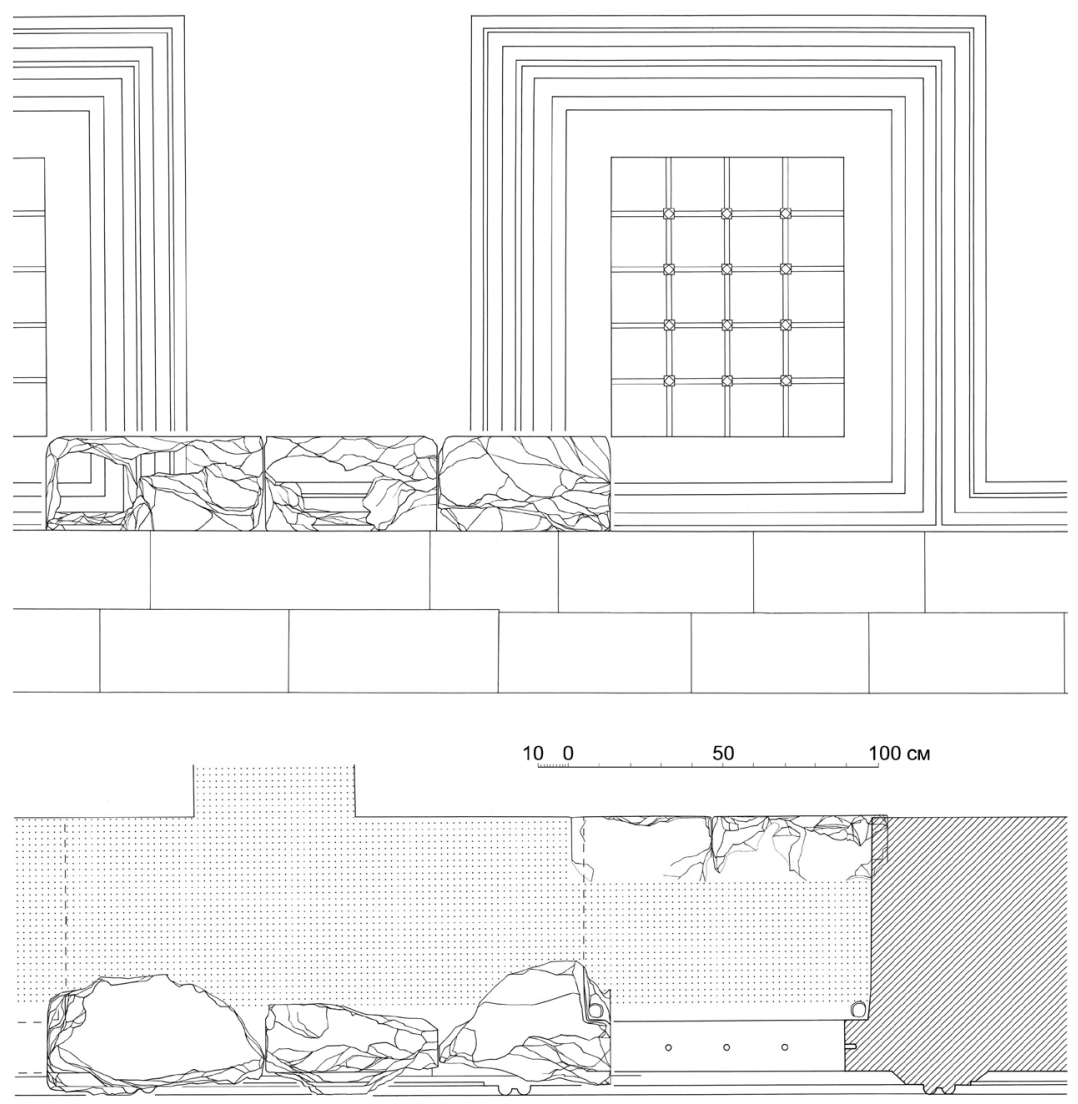

Ил. 6. Среднее окно в южной части передней стены медресе. Вид и план. Реконструкция. Пунктирной сеткой обозначена современная консервационная кладка, перекрывшая первоначальную конструкцию. Чертеж автора

Fig. 6. The middle window in the southern part of the front wall of the medrese. A view and ground plan. Reconstruction drawing. The dotted grid indicates the modern conservation masonry overlapping the original structure. Drawn by the author 
В. П. Кирилко

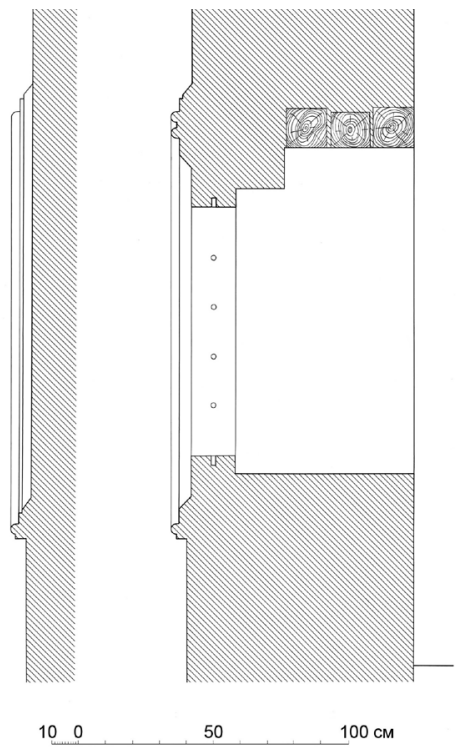

Ил. 7. Среднее окно в южной части передней стены медресе. Разрезы по простенку и проему. Реконструкция. Чертеж автора

Fig. 7. The middle window in the southern part of the front wall of the medrese. Cross-sections by the pier and doorway. Reconstruction drawing. Drawn by the author

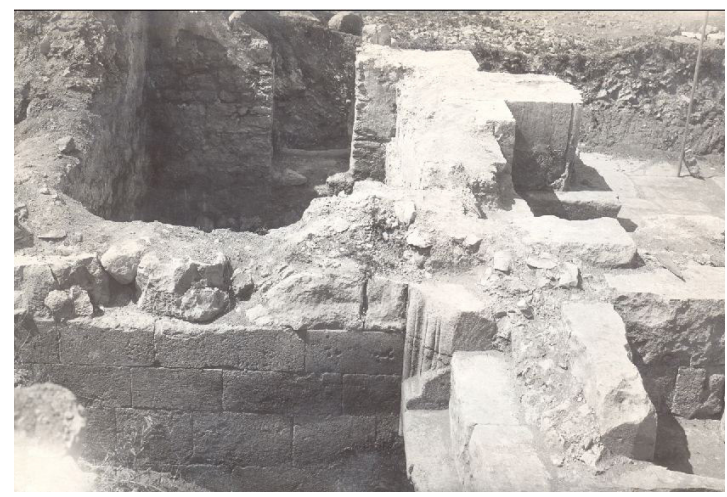

Ил. 8. Обрамление передней стены медресе. Фрагмент. Вид с востока. 1928 (по: Кирилко В. П. Солхатское медресе... Рис. 13)

Fig. 8. The border of the front wall of the medrese. Fragment. Viewed from the east. 1928 (according to: Kirilko, V. P. Solhatskoe medrese... Fig. 13) 
Некоторые архитектурные детали крымского медресе

Сохранившийся фрагмент профилированного выступа над цоколем находится между двумя проемами, предназначавшимися для освещения соседних худжр (пом. 3 и 4). Судя по уцелевшим остаткам лицевой поверхности, тяга имела ломаную конфигурацию и состояла из сведенных под прямым углом отдельных участков одинакового сечения, располагавшихся попеременно горизонтально и вертикально (ил. 5-6). С учетом пластики утраченных деталей декора, которые запечатлены на старых фотоснимках (ил. 8), есть основание считать, что первоначально она полностью обрамляла стену по периметру, одновременно оконтуривая с боков и сверху наличники окон. Примеры подобного оформления фасадов в средневековой мусульманской архитектуре известны, а самой близкой аналогией ему является резное убранство мечети Ешиль-Джами в Бурсе, построенной в 1412-1424 гг. ${ }^{21}$

Южная половина передней стены медресе имела три одинаковых окна (ил. 1) ${ }^{22}$. Судя по остаткам одного из них (среднего), наиболее уцелевшего и непосредственно связанного с фрагментом профилированного выступа над цоколем, они представляли собой прямоугольные в плане проемы с четвертями, украшенными снаружи рельефными наличниками (ил. 6-7). Свидетельством этому являются частично сохранившийся откос, локально развернутый по отношению к плоскости

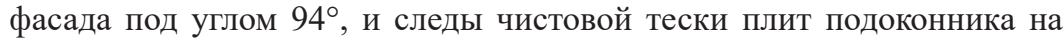
боковых кромках, которые четко обозначили лицевую и рабочую поверхности конструкции (ил. 9).

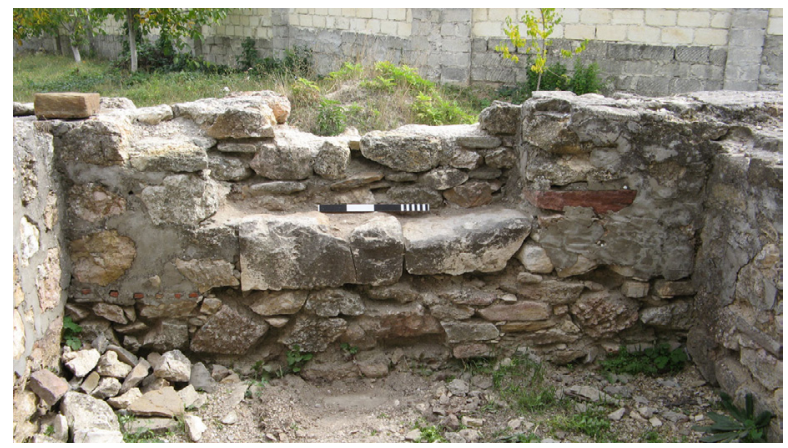

Ил. 9. Среднее окно в южной части передней стены медресе. Вид с запада. 2009. Фото автора

Fig. 9. The middle window in the southern part of the front wall of the medrese. Viewed from the west. 2009. Photographed by the author

${ }^{21}$ Kuran A. The Mosque in Early Ottoman Architecture. Chicago and London, 1968. P. 115.

${ }^{22}$ Кирилко В. П. Солхатское медресе... С. 159-162. 


\section{В. П. Кирилко}

Предположительно, окно было прямоугольной формы, с металлической решеткой и внутренними ставнями, имело деревянное перекрытие в виде сплошного наката из дубовых брусьев. Его реконструируемые размеры: просвет - 0,75 м, высота $-0,9 \mathrm{~m}^{23}$. Ширина четверти равна 16,5 см. Ее толщина составляла 6,5 см. Гнездо подпятника находится в углу, на расстоянии 1 см от поверхности проема. Оно имеет вид усеченного конуса с небольшим уплощением спереди и скругленным дном. Диаметр и глубина выемки $-4,8$ см. Ширина окна со стороны помещения составляет 0,93 м, у самой четверти посредством излома откоса она уменьшается до 0,9 м. Глубина амбразуры - 0,66 м. Высота подоконника - 0,7 м, проема - около 1,2 м.

В отличие от южной части северная половина передней стены медресе имела всего лишь одно окно (ил. 1) 24 . Обе стороны отличались между собой также разным количеством и неодинаковым расположением каменных водосточных желобов (ил. 10), которые выступали наружу на 0,23 м ${ }^{25}$ с шагом 2,25, 2,8 и 3,6 м. Следовательно, несмотря на наличие четко выделенного центра и доминанты в виде монументального портала, обозначившего продольную ось здания, главный фасад был асимметричным.

Компенсировать образовавшуюся неуравновешенность композиции и придать внешнему виду строения цельность могло дополнительное декорирование плоскости стены рельефными медальонами и орнаментальными лентами. В частности, достаточно большой представ-

\footnotetext{
${ }^{23}$ Исключительную точность реконструируемых внешних размеров окна наряду с хорошо сохранившимися in situ остатками самого сооружения обеспечивает четко фиксируемая порядовка кладки, которая, судя по смежному с главным фасадом уцелевшему участку боковой стены, строителями старательно выдерживалась и имела высоту 1,21 м. Уровни нижних плоскостей кордона цоколя и архитрава проема совпадают с ее отметками, что, в свою очередь, позволяет получить реальное представление о величине самой архитектурной детали.

${ }^{24}$ Кирилко В. П. Солхатское медресе... С. 159-162.

${ }^{25}$ Реконструируемые размеры водомета и его технические характеристики, которые при первой публикации находки могли быть определены только по фотографии (Там же. C. 174, рис. 78), сейчас, после обнаружения самой детали, подлежат уточнению. Изделие представляет собой прямоугольный блок известняка с четко выраженным сужением спереди, оформленным в виде половины усеченного конуса. Тыльный торец утрачен, боковые поверхности на краях повреждены сколами. Общие размеры фрагмента: длина - 89 см, толщина - 17 см, ширина - около 31 см. Верхняя грань водостока плоская, имеет трапециевидную в плане сужающуюся наружу продольную выемку с относительно ровными бортами и дном. Просвет желоба - 6-18 см, его глубина $-4,4$ см. Вынос равен 23 см. Ширина выступавшей за пределы стены части блока составляет 16,6-24 см, ее толщина - 10,5-15 см. Внешний торец скошен книзу под углом $87^{\circ}$. Форма изделию придана посредством слегка небрежной околки глубиной до 1 см, после чего верхняя грань, желоб и внешний конец детали дополнительно были выровнены зубчатым резцом.
} 
Некоторые архитектурные детали крымского медресе
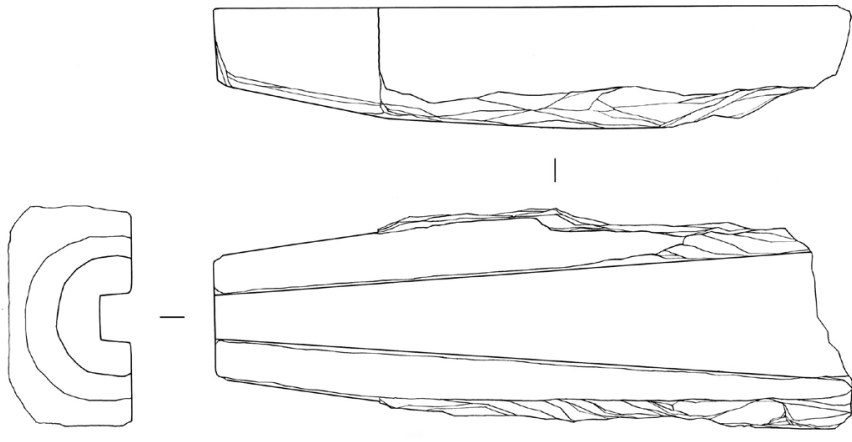

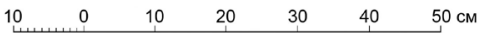

Ил. 10. Водосточный желоб. Виды и план. Обмер. Чертеж автора

Fig. 10. A drain gutter. Its views and the plan. Measurement. Drawn by the author

ляется вероятность того, что именно для этой цели предназначались блоки с резной геометрической плетенкой на лицевой поверхности, обломки которых, преимущественно беспаспортные, массово представлены в лапидарии памятника.

Фотография одного из таких фрагментов, полученного непосредственно при археологическом изучении медресе, опубликована М. Г. Крамаровским ${ }^{26}$. Впервые сообщая о находке, автор раскопок счел возможным отнести ее к числу «остатков портала» ${ }^{27}$. Хотя гирих и является важнейшей составной частью декоративного обрамления парадных входов, вывод исследователя небесспорен, поскольку известно, что эта и некоторые другие, подобные ей, архитектурные детали, вторично применявшиеся в качестве обычного кладочного материала, были обнаружены в подпорной стене некрополя. Последняя же, в свою очередь, появилась не ранее конца XVI в. и, надо полагать, не позднее 1780-х гг., когда, судя по рисунку М. М. Иванова (ил. 3), где она изображена на втором плане, портал еще пребывал в удовлетворительном состоянии и вряд ли стал бы источником для этих сполий. Ошибочным необходимо признать также мое предположение о том, что данная плетенка

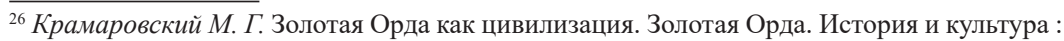
каталог выставки / ред. М. Б. Пиотровский. СПб., 2005. С. 114. Кат. 214; Он же. Человек средневековой улицы. Золотая Орда. Византия. Италия. СПб., 2012. С. 214, рис. 55.

${ }^{27}$ Он же. Работы на городище Солхата // Археологические открытия 1980 года. М., 1981. C. 265-266. 


\section{В. П. Кирилко}

использовалась для оформления наличника михраба в южном айване здания, чему нет подтверждения ${ }^{28}$.

На главном фасаде солхатского медресе лента с резным геометрическим орнаментом, вероятнее всего, располагалась вдоль профилированного выступа и могла быть замкнута по периметру на уровне пят сводов, образуя прямоугольную рамку в верхней части плоскости стены. Поскольку прямые аналогии подобного композиционного решения не известны, данную реконструкцию пока следует считать исключительно гипотетической.

Самым проблематичным является подробное воссоздание первоначального облика портала, несмотря на то, что его вид известен по акварели М. М. Иванова. На данном этапе исследований уверенно можно судить только о единичных, соотносимых с ним археологических находках ${ }^{29}$, но их количество недостаточно для обоснованной реконструкции сооружения. В настоящий момент не вызывает особых сомнений разве что использование для внешнего обрамления портала сплошной профилированной тяги, которая позволяла выделить, четко ограничив с боков и сверху, основные поверхности его фасадов (ил. 11). Нижние части рельефного выступа хорошо сохранились in situ на южном пилоне (ил. 4), а сам он имеет параллели в средневековом зодчестве Малой Азии, например, при оформлении северного входа Улу Джами в Дивриги, датированной 1229 г. $^{30}$

Графическое восстановление всего портала в мельчайших подробностях, как, впрочем, и ряда других, пока до конца не ясных, отдельных мест здания, хочется верить, дело недалекого будущего, которое в значительной мере зависит от введения в научный оборот абсолютно всех архитектурных, конструктивных и декоративных деталей, найденных на территории Старого Крыма и особенно тех, что были получены при раскопках медресе. Обязательным условием результативности является наличие исчерпывающей и достоверной информации о них, равно как качественных обмерных чертежей и фотографий.

К настоящему времени итоги археологического изучения солхатского медресе, правда, исключительно предварительные, автором раскопок подводились, по меньшей мере, трижды ${ }^{31}$. Самые последние из них, определяемые одновременно и как первостепенные задачи (sic!), вроде бы вселяют надежду на то, что многочисленные материалы исследований памятника, накопление которых было начато М. Г. Крамаровским

\footnotetext{
${ }^{28}$ Кирилко В. П. Солхатское медресе... С. 181 , рис. 81.

${ }^{29}$ Там же. С. $166-170$, рис. $68-69$.

${ }^{30}$ Goodwin G. A history of Ottoman architecture. London, 1992. P. 51, fig. 44.

${ }^{31}$ Крамаровский М. Г. Золотая Орда... С. 113-114; Он же. Человек средневековой улицы... С. 209-214; Он же. Золотоордынская (Старокрымская) экспедиция // Экспедиции. Археология в Эрмитаже / ред. А. Ю. Алексеев, А. М. Бутягин. СПб., 2014. С. 145; Крамаровский М. Г., Сейдалиев Э. И. Археологические исследования... С. 325.
} 
Некоторые архитектурные детали крымского медресе

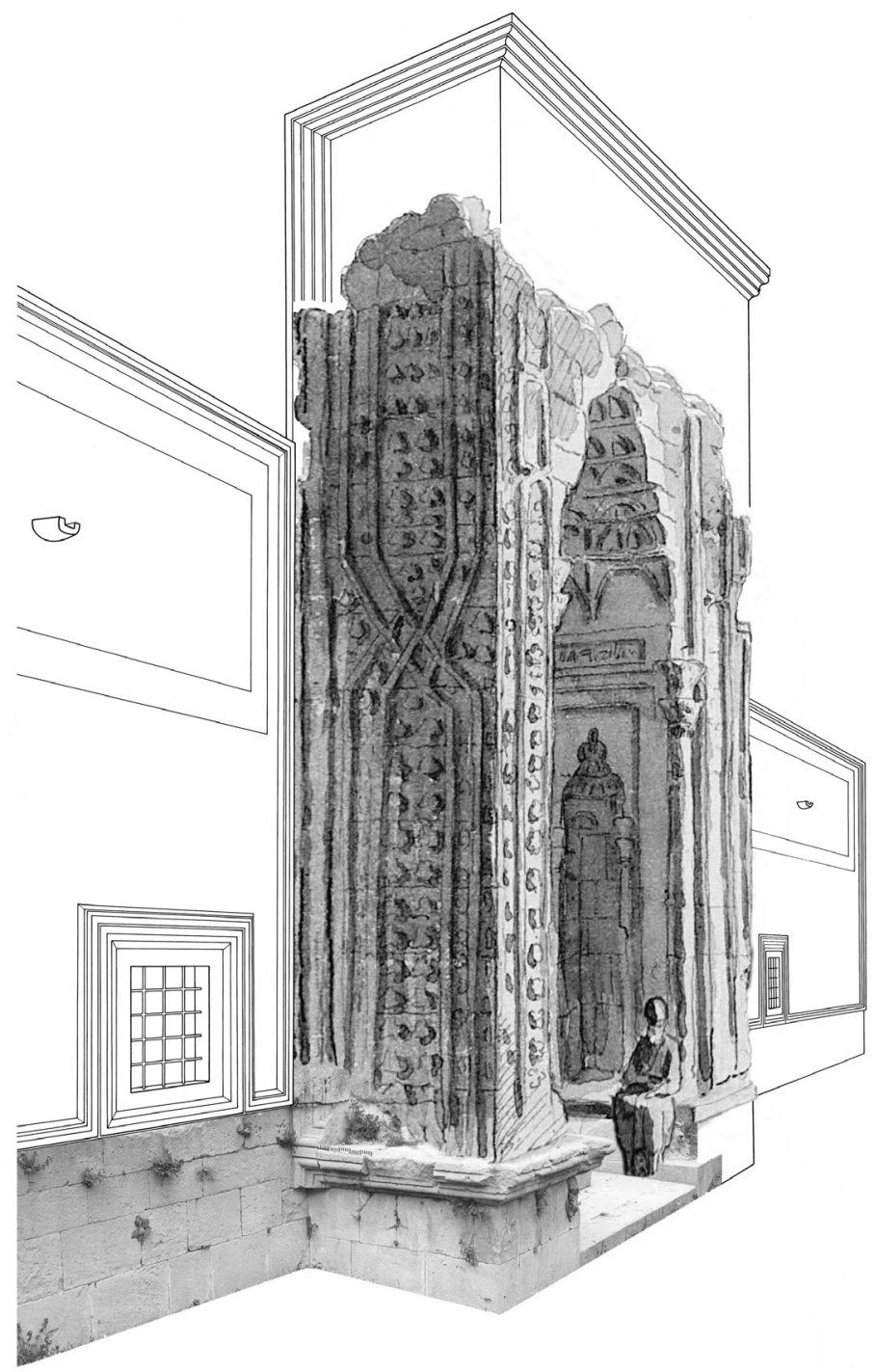

Ил. 11. Портал медресе. Вид с юго-востока. Реконструкция. Чертеж автора Fig. 11. The portal of the medrese. Viewed from the south-east. Reconstruction drawing. Drawn by the author 


\section{В. П. Кирилко}

еще сорок с лишним лет назад, наконец-то будут опубликованы и станут доступными широкому кругу специалистов, а следовательно, позволят более углубленно рассмотреть архитектонику этого уникального здания. Медресе Инджи-бей Хатун является одним из немногих раритетных строений средневекового Крыма, полноценная реконструкция которого не только возможна, причем с высокой степенью достоверности, но и, по большому счету, не составляет особого труда, как, впрочем, и качественная научно обоснованная консервация его руин.

\section{REFERENCES}

Aleksandrova, N. (2000). Zhan Baltazar de la Travers. "Puteshestvuiushchii po Rossii zhivopisets" [Jean Balthazar de la Travers. "Painter Traveling in Russia"]. Moscow: Zhiraf.

Bashkirov, A. S (1926). Sel'dzhukizm v drevnem tatarskom iskusstve [Seljukism in Ancient Tatar Art]. Krym, 2, 108-125.

Bocharov, S. G., \& Sitdikov, A. G. (Eds.). (2016). Miras - Nasledie. TatarstanKrym. Gorod Bolgar i izuchenie tatarskoi kul tury v Tatarstane i Krymu v 1923-1929 godakh [Miras - Legacy. Tatarstan - Crimea. The City of Bolgar and the Study of Tatar Culture in Tatarstan and Crimea in 1923-1929] (Vols. 1-3). Kazan: Aster Plus.

Ernst, N. L. (1930). Letopis' arkheologicheskikh raskopok i razvedok v Krymu za 10 let (1921-1930) [Chronicle of Archaeological Excavations and Exploration in the Crimea for 10 Years (1921-1930)]. Izvestiia Tavricheskogo obshchestva istorii, arkheologii i etnografii, 4, 72-92.

Goodwin, G. (1992). A History of Ottoman Architecture. London: Thames and Hudson.

Kirilko, V. P. (2011). Solkhatskoe medrese [Solkhat Madrasah]. Stratum plus, 6, 125-210.

Kirilko, V. P. (2014). Restavratsiia arkhitekturnogo kompleksa XIV-XVI vv. "Medrese-mechet' Uzbeka v g. Staryi Krym": uspekhi, neudachi i perspektivy [Restoration of the Architectural Complex of the Fourteenth-Seventeenth Centuries. "Madrasah-Mosque of Uzbek in the Old Crimea": Successes, Failures and Prospects]. In A. Ismailov, E. Muratova, \& S. Eminova (Eds.), Aktual'nye problemy izucheniia i sokhraneniia islamskogo naslediia v Krymu [Actual Problems of Studying and Preserving the Islamic Heritage in Crimea] (pp. 82-88). Simferopol: G. N. Muzafarov SPD.

Kirilko, V. P. (2015a). Portal krymskoi mecheti Uzbeka [Portal of the Crimean Uzbek Mosque]. Stratum plus, 6, 253-274.

Kirilko, V. P. (2015b). Stroitel'naia periodizatsiia t.n. mecheti Uzbeka v Starom Krymu [Construction Periodization of the So-called Uzbek Mosque in Old Crimea]. In S. G. Bocharov, \& A. G. Sitdikov (Eds.), Genuezskaia Gazariia i Zolotaia Orda [Genoese Gazaria and the Golden Horde] (pp. 509-558). Kishenev: Stratum Plus.

Kirilko, V. P. (2016). Spolii v arkhitekture Krymskogo khanstva [Spoli in the Architecture of the Crimean Khanate]. In H. M. Abdullin, \& A. G. Sitdikov (Eds.), Materialy Kongressa islamskoi arkheologii Rossii i stran $S N G$ [Materials of the Congress of Islamic Archeology of Russia and the CIS] (pp. 160-170). Kazan: Institut arkheologii AN RT. 
Некоторые архитектурные детали крымского медресе

Kramarovskii, M. G. (1981). Raboty na gorodishche Solkhata [Works on the Settlement of Solkhat]. In B. A. Rybakov (Ed.), Arkheologicheskie otkrytiia 1980 goda [Archaeological Discoveries in 1980] (pp. 265-266). Moscow: Nauka.

Kramarovskii, M. G. (2005). Zolotaia Orda kak tsivilizatsiia [The Golden Horde as a Civilization]. In M. B. Piotrovskiy (Ed.), Zolotaia Orda. Istoriia i kul'tura: katalog vystavki [Golden Horde. History and Culture: Exhibition Catalogue] (pp. 13-172). Saint Petersburg: Slaviia.

Kramarovskii, M. G. (2012). Chelovek srednevekovoi ulitsy. Zolotaia Orda. Vizantiia. Italiia [Medieval Street Man. Golden Horde. Byzantium. Italy]. Saint Petersburg: Evrazia.

Kramarovskii, M. (2014a). Kompleks mecheti i medrese Solkhata: aktual'nye problemy izucheniia i sokhraneniia [Complex of the Mosque and Madrasah of Solkhat: Topical Problems of Study and Preservation]. In A. Ismailov, E. Muratova, \& S. Eminova (Eds.), Aktual'nye problemy izucheniia i sokhraneniia islamskogo naslediia Kryma [Actual Problems of Studying and Preserving the Islamic Heritage of Crimea] (pp. 2015-213). Simferopol: Tarpan Publ.

Kramarovskii, M. G. (2014b). Zolotoordynskaia (Starokrymskaia) ekspeditsiia [Golden Horde (Starokrymskaya) Expedition]. In A. Iu. Alekseev, \& A. M. Butiagin (Eds.), Ekspeditsii. Arkheologiia v Ermitazhe [Expeditions. Archeology in the Hermitage] (pp. 138-153). Saint Petersburg: Slaviia.

Kramarovskii, M. G., \& Seidaliev, E. I. (2019). Arkheologicheskie issledovaniia Starokrymskoi arkheologicheskoi ekspeditsii Gosudarstvennogo Ermitazha v 2001-2018 gg.: itogi i perspektivy [Archaeological Research of the Old Crimean Archaeological Expedition of the State Hermitage in 2001-2018: Results and Prospects]. In V. N. Zin'ko \& E. A. Zin'ko (Eds.), XX Bosporskie chteniia. Bospor Kimmeriiskii $i$ varvarskii mir $v$ period antichnosti i srednevekov'ia. Osnovnye itogi i perspektivy issledovanii [XX Bosporus Readings. Bosporus Cimmerian and Barbarian World in the Period of Antiquity and the Middle Ages. Main Results and Perspectives of Research] (pp. 324-346). Simferopol; Kerch: [s.n.].

Kuran, A. (1968). The Mosque in Early Ottoman Architecture. Chicago; London: The University of Chicago Press.

Mal'gina, M. R. (Ed.). (2017). Vidy Kryma iz putevogo al'boma M. M. Ivanova (k 270-letiiu so dnia rozhdeniia khudozhnika) [Views of Crimea from M. M. Ivanov's Travel Album (to the 270 ${ }^{\text {th }}$ Anniversary of the Artist's Birth)]. Simferopol: New Orianda.

Petrova, E. B. (2015). Istoricheskii i khudozhestvennyi al 'bom Tavridy Evgeniia de Vil'neva $i$ Vikentiia Russena [Historical and Artistic Album of Tavrida by Evgeny de Villeneuve and Vincent Russen]. Feodosiia; Simferopol: New Orianda.

\section{Кирилко Владимир Петрович}

кандидат исторических наук, старший научный сотрудник

Институт археологии Крыма РАН

295007, Симферополь, пр. Академика

Вернадского, 2

E-mail:kir.vlad33@gmail.com

\section{Kirilko, Vladimir Petrovich}

$\mathrm{PhD}$ (History), Senior Researcher

Institute of Archaeology of the Crimea

of the Russian Academy of Sciences

2 Academician Vernadsky Ave, Simferopol, 295007, Russia

E-mail: kir.vlad33@gmail.com

ORCID: 0000-0002-5431-9127

ScopusID: 56525254700 